\title{
EFFECT OF SPATIAL ARRANGEMENT AND FOLIAR APPLICATION OF GROWTH REGULATING HORMONE ON THE FLOWER HEAD DEVELOPMENT OF COCKSCOMB UNDER THE TROPICAL ARID ENVIRONMENT OF SOUTHERN PUNJAB, PAKISTAN
}

\author{
Arslan Asim, Researcher \\ Department of Horticulture, Faculty of Agriculture Science and Technology \\ Bahauddin Zakariya University Multan, Pakistan
}

Dr. Muhammad Maqbool, Syed Amir Manzoor, Researchers

Department of Forestry and Range Management, Faculty of Forestry, Range Management and Wildlife, PMAS - Arid Agriculture University, Rawalpindi, Pakistan

\author{
Seema Mahmood, Researcher \\ Institute of Pure and Applied Biology, Bahauddin Zakariya University, Multan, Pakistan
}

\author{
Ahsan Irshad, Ali Ammar, Researchers \\ Regional Agriculture Research Institute, Bahawalpur, Pakistan \\ Phone: +92-31-36099702, Fax: +92-61-6564100 \\ E-mail: arslanasim92@gmail.com
}

\begin{abstract}
This investigation was carried out at Experimental Farm, Faculty of Agriculture Science and Technology, Bahauddin Zakariya University, Multan (Pakistan). The objective of this study was to produce high quality Celosia flower head as cut flower under the harsh environmental conditions of southern Punjab by using different plant spacing and different concentrations of Gibberellin $\left(\mathrm{GA}_{3}\right)$. The seedlings were grown by seed and then transplanted in the field in the first week of August. Seedlings were irrigated daily and fertilized with 100 ppm NPK solution with alternate irrigation before transplanting. Field was well prepared by irrigation and spading twice and adding about $1.5 \mathrm{~kg}$ Diammonium phosphate (DAP) at the rate of 150 $\mathrm{kg} / \mathrm{hectare}$ as phosphorus source, about $2 \mathrm{~kg}$ Muriate of Potash (MOP) at the rate of 200 $\mathrm{kg} / \mathrm{hectare}$ as potash source and about $1 \mathrm{~kg}$ urea at the rate of $100 \mathrm{~kg} /$ hectare as nitrogen source prior to transplanting. Then, seedlings were transplanted in randomized complete block design. There were three levels/concentrations of $\mathrm{GA}_{3}(0,25$ and $50 \mathrm{mg} / \mathrm{l})$ and three levels of plant spacing $(22.50,30.00$ and $37.50 \mathrm{~cm})$ making overall 9 treatments and these treatments were tested in 3 replications. The analysis of variance indicated that best results were achieved when plant spacing of $37.5 \mathrm{~cm}$ was used in combination with $\mathrm{GA}_{3}$ application (at the rate of $50 \mathrm{mg} / \mathrm{l}$ ) where significant increase in chlorophyll contents, leaf area and number of leaves, fresh and dry weight of stem, flower diameter and fresh and dry weight of flower of Celosia cristata were found compared to all other treatments tested.
\end{abstract}

\section{KEYWORDS}

Celosia cristata; Cockscomb; Flower head; Gibberellin.

Celosia cristata, a member of amaranth family (Amaranthaceae) is an annual crop grown usually for landscape purpose. Some of its hybrid cultivars are commercially used as cut flowers as well. Celosia is commonly known as "Cockscomb" or "Kalgha" because of its resemblance to roosterhead (Wilkinson et al., 2006).C. cristata is known to have a great potential being cut flower. Over the years, the demand of high quality celosia cut flower has increased manifolds owing to its unique appearance and longer shelf life. Thus, to meet such demand, there must be availability of variety of high quality cut flower throughout the year.

The production of high quality $C$. cristata flower head in tropical arid regions like those of Southern Punjab (Pakistan) has been a considerable problem since the harsh environmental conditions pose a significant threat to the appropriate growth and flower head 
development in cockscomb (Edward et al., 1934). In the current study we did experiment with a range of plant spacing treatments in combination with foliar application of different concentrations of growth regulating hormone to achieve the desired flower head. In fact, plant to plant spacing has been recognized as a pivotal factor to the quality of end product in all agronomic and horticultural crops. It is possible only through optimum plant to plant spacing that maximum and unchecked growth of plants can be achieved. Moreover, it is proved that plant growth regulators including gibberellins contribute in different ways towards better plant growth. Out of many types of gibberellins, gibberellic acid $\left(\mathrm{GA}_{3}\right)$ is in active form and is extensively used in agriculture. Mainly, it helps in plant growth by cell elongation (Brian, 2008). Stem length and flower size are known quality factors for better acceptance by the consumers and fetch better price in the market. Hence gibberellic acid is used to achieve these parameters.

Since no significant study has been carried out in the past on cockscomb regarding improvement of its production in less favorable climatic conditions, the current study was aimed at finding out the most appropriate plant spacing as well as dosage of GA3 application on Cockscomb to improve its quality under the harsh tropical arid environment of outher Punjab, Pakistan.

The study therefore aimed at investigating following target areas of Cockscomb field production as cut flower:

- Effect of growth promoter $\left(\mathrm{GA}_{3}\right)$ on plant growth and flower head quality of Celosia cristata in agro-climatic field conditions of Multan;

- Effect of different plant spacing on plant growth and flower head quality of Celosia cristata in agro-climatic field conditions of Multan.

\section{MATERIAL AND METHODS}

Site. This study was conducted at the Experimental Farm, Faculty of Agriculture Science and Technology, Bahauddin Zakariya University Multan during the summer 2011.

Collection of Seed and Raising Seedlings. Hybrid seed $\left(\mathrm{F}_{1}\right)$ of cockscomb (Celosia cristata) was purchased from Pak Seed Co. Lahore, Pakistan. Seeds were sown in pots in the first week of July for raising seedlings. Media in pots comprised of well homogenized soil, silt and well rotten farm yard manure in ratio 1:1:1. After one week's time, seedlings were shifted from pots to plastic bags which were 3 inches in diameter and 8 inches in length. Seedlings were irrigated on daily basis till these were transplanted in the field.

Field Preparation and Transplanting Seedlings. After three weeks' time, seedlings were transplanted to field when seedlings showed two true leaves. Prior to transplanting, field was prepared by irrigation and spading twice and adding about $1.5 \mathrm{~kg}$ DAP (at the rate of $150 \mathrm{~kg} /$ hectare), about $2 \mathrm{~kg} \mathrm{MOP}$ (at the rate of $200 \mathrm{~kg} /$ hectare) and about $1 \mathrm{~kg}$ urea (at the rate of $100 \mathrm{~kg} /$ hectare).

Experimental Design and Treatments. $\mathrm{GA}_{3}$ and Plant spacing were the two factors in this study. There were three levels of $\mathrm{GA}_{3}(0,25,50 \mathrm{mg} / \mathrm{l})$ and three plant spacing $(22.50$, $30.00,37.50 \mathrm{~cm})$ making overall 9 treatments $\left(\mathrm{T}_{1}=0 \mathrm{mg} / \mathrm{L} \times 22.5 \mathrm{~cm}, \mathrm{~T}_{2}=0 \mathrm{mg} / \mathrm{L} \times 30 \mathrm{~cm}, \mathrm{~T}_{3=}\right.$ $0 \mathrm{mg} / \mathrm{L} \times 37.5 \mathrm{~cm}, \mathrm{~T}_{4=} 25 \mathrm{mg} / \mathrm{L} \times 22.5 \mathrm{~cm}, \mathrm{~T}_{5=} 25 \mathrm{mg} / \mathrm{L} \times 30 \mathrm{~cm}, \mathrm{~T}_{6=} 25 \mathrm{mg} / \mathrm{L} \times 37.5 \mathrm{~cm} . \mathrm{T}_{7=}$ $\left.50 \mathrm{mg} / \mathrm{L} \times 22.5 \mathrm{~cm}, \mathrm{~T}_{8=} 50 \mathrm{mg} / \mathrm{L} \times 30 \mathrm{~cm}, \mathrm{~T}_{9=} 50 \mathrm{mg} / \mathrm{L} \times 37.5 \mathrm{~cm}\right)$. All treatments were tested in 3 replications in a randomized complete block design (RCBD) with 25 seedlings for each treatment unit.

\section{DATA COLLECTION AND STATISTICAL ANALYSIS}

After 90 days, plant responses from all treatments were recorded in terms of leaf chlorophyll content, number of leaves per stem, leaf area, stem length, stem fresh weight, stem dry weight, flower head area, flower head fresh weight and flower head dry weight. The data collected were subjected to statistical analysis as analysis of variance (ANOVA) and Least Significant Difference (LSD) at 5\% level of significance as given by Steel et al. (1997) using MSTAT-C, computer software (Bricker, 1991). 


\section{RESULTS AND DISCUSSION}

Effect On Chlorophyll Content. Statistical analysis indicates that maximum chlorophyll content of 83.54 was achieved in treatment $T_{9}$ when plants were spaced at $37.5 \mathrm{~cm}$ apart and treated with $50 \mathrm{mg} / \mathrm{L} \mathrm{GA}_{3}$ and this treatment was sianificantly different from all other treatments. Minimum chlorophyll content was repor Standard Error=2.83 treatment $T_{9}$ with no $\mathrm{GA}_{3}$ application. In fact, Gibberellins plays a crucial Tole in cell elongation of plants. Better growth and increased leaf area which in turn yielded higher number of chlorophyll content has been possible due to ample space available for the plant growth plus the application of $50 \mathrm{mg} / \mathrm{L} \mathrm{GA}$. Similar results were obtained in Lily (Emami et al., 2011).

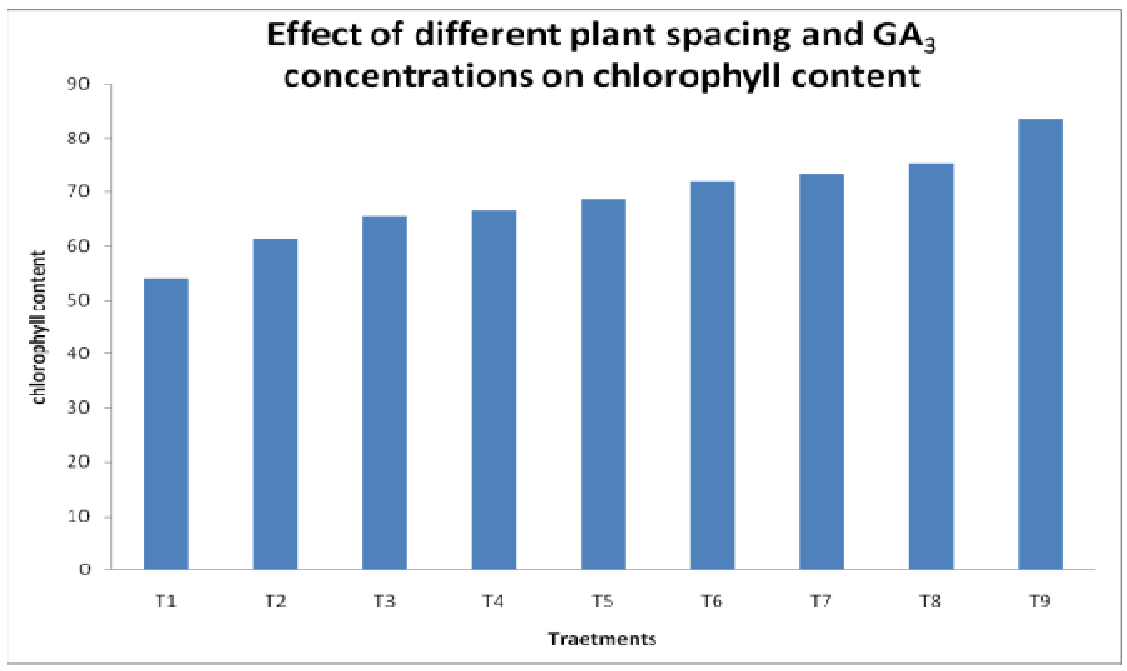

Figure 1 - Effect of different plant spacing and $\mathrm{GA}_{3}$ concentrations on chlorophyll content

Leaf Area $\left(\mathrm{cm}^{2}\right)$. Maximum leaf area of $154.34 \mathrm{~cm}^{2}$ was achieved when plants were spaced $37.5 \mathrm{~cm}$ apart and treated with $50 \mathrm{mg} / \mathrm{L}$ of $\mathrm{GA}_{3}\left(\mathrm{~T}_{9}\right)$ and it was significantly different from all other treatments. The minimum leaf area of $134.85 \mathrm{~cm}^{2}$ was produced with $22.5 \mathrm{~cm}$ plant spacing when no $\mathrm{GA}_{3}$ was applied $\left(\mathrm{T}_{1}\right)$. Greater leaf area allows maximum exposure to light thus causing higher levels of carbohydrates to be fixed in plant. Hence this spacing, in combination with $\mathrm{GA}_{3}(50 \mathrm{mg} / \mathrm{L})$ plays a significant role in the growth and development of Cockscomb and ultimately contributes to quality production of flower heads. These findings are in accordance with the findings of Akinfasoye et al., (2008) in Celosia; Yarniaet al., (2011) in Amaranthus; Chandrappa et al. (2006) in Anthurium; Peanav et al., (2005) in gladiolus and Khan et al. (2003) in Dahlia.

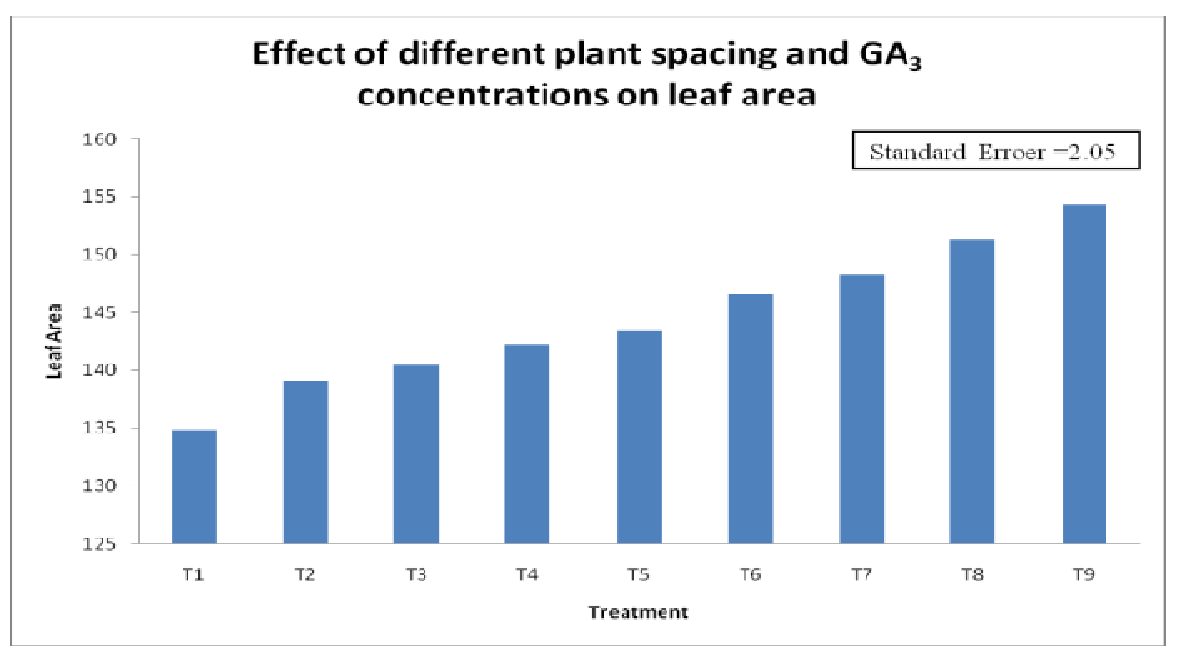

Figure 2 - Effect of different plant spacing and $\mathrm{GA}_{3}$ concentrations on leaf area 
Stem Length (cm). Study has revealed that maximum stem length of $69.30 \mathrm{~cm}$ and $65.5 \mathrm{~cm}$ was achieved with the application of $50 \mathrm{mg} / \mathrm{L} \mathrm{GA}$ with plant spacing of $37.5 \mathrm{~cm}$ and $30.0 \mathrm{~cm}$ ( $\mathrm{T}_{9}$ and $\mathrm{T}_{8}$ respectively), though these were statistically different from one another. On the other extreme, minimum stem length of $51.77 \mathrm{~cm}$ was achieved when plants did not receive any $\mathrm{GA}_{3}$ treatment and were planted at a distance of $22.5 \mathrm{~cm}$ apart $\left(\mathrm{T}_{1}\right)$. It is evident from the data that plant spacing and $\mathrm{GA}_{3}$ play a vital role in quality production of celosia cristataas cut flower. It seems that $37.5 \mathrm{~cm}$ plant spacing is ideal for better growth where these plants grow without any competition with neighboring plants. $\mathrm{GA}_{3}$ is also well known for cell elongation and this concentration of $(50 \mathrm{mg} / \mathrm{L})$ is the most suitable dose for getting appropriate stem length that is well accountable in cut flower production. Similar studies were done on Marigold by Kishan et la., (2007); on Anthurium by Chandrappa et al., (2006); on gladiolus (Bhattacharjee, 1984; Bhushan et al.,2006 ;Roychowdhury., 1987 ; Peanavet al., 2005), tuberose (Khalajet al., 2012 ; Mane et al., 2006) and on Black Iris (Al-Khassawneh et al.,(2005).

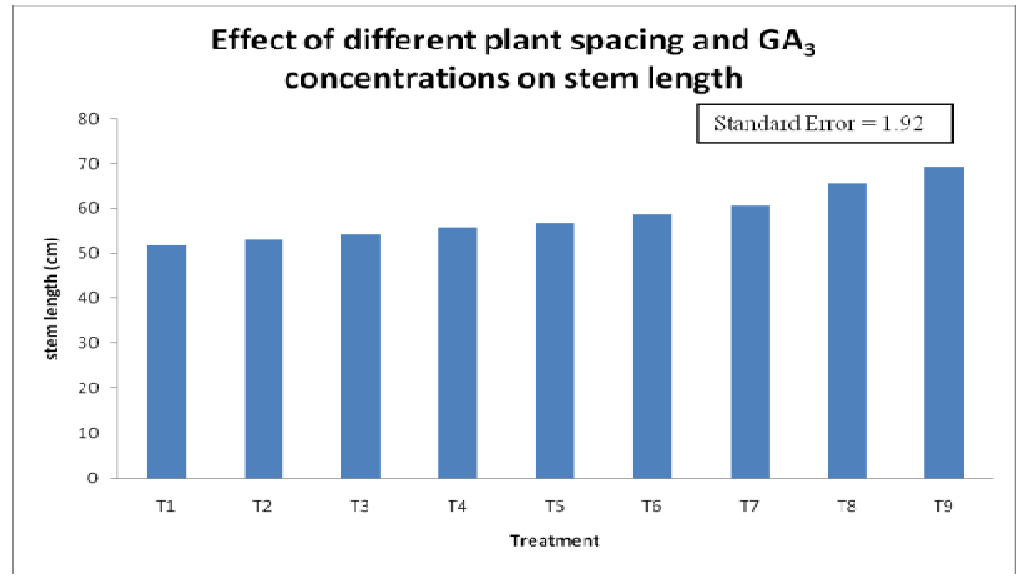

Figure 3 - Effect of different plant spacing and $\mathrm{GA}_{3}$ concentrations on stem length

Fresh weight of Stem (g). This study shows that the maximum fresh weight of stem $(742.99 \mathrm{~g})$ was achieved when plant spacing $37.5 \mathrm{~cm}$ was used with application of $50 \mathrm{mg} / \mathrm{L}$ $\mathrm{GA}_{3}\left(\mathrm{~T}_{9}\right)$. This treatment was followed by combination of $30 \mathrm{~cm}$ plant spacing and application of $50 \mathrm{mg} / \mathrm{L} \mathrm{GA} \mathrm{G}_{3}\left(\mathrm{~T}_{8}\right)$ which produced stem fresh weight of $731.86 \mathrm{~g}$. Minimum stem fresh weight was produced when plant spacing of $22.5 \mathrm{~cm}$ and $30 \mathrm{~cm}$ was used $\left(T_{1}\right.$ and $T_{2}$ respectively) without any $\mathrm{GA}_{3}$ application. Fresh weight basically is due to water uptake of plants during development. It seems that this treatment combination $\left(T_{9}\right)$ has helped the plant to establish more number of roots which ultimately helped the plant in updating greater water content. These findings are comparable to the results of Yarnia et al., (2011) in Amaranth; kazaz et al., (2011) in Carnation and Emami et al., (2011) in Lilium longiflorium.

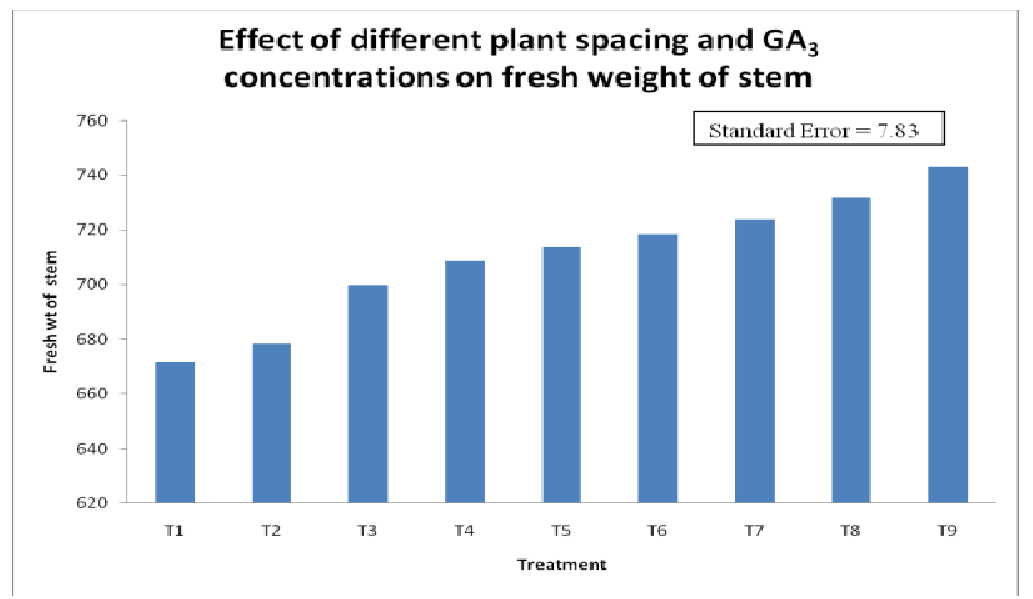

Figure 4 - Effect of different plant spacing and $\mathrm{GA}_{3}$ concentrations on fresh weight of stem 
Dry Weight of Stem $(\mathrm{g})$. It is evident from the data that maximum dry weight of stem (56.44g) was achieved when plant spacing of $37.5 \mathrm{~cm}$ was used and $50 \mathrm{mg} / \mathrm{L} \mathrm{GA}$ was applied $\left(\mathrm{T}_{9}\right)$. Minimum stem dry weight of $39.36 \mathrm{~g}$ was achieved when plant spacing of 22.5 $\mathrm{cm}$ was used without $\mathrm{GA}_{3}$ application $\left(\mathrm{T}_{1}\right)$. In fact, dry weight of plants is always dependent on the photosynthetic efficiency of plants. Leaves play a vital role in manufacturing plant food in the presence of optimum daylight. It is clear from the data that more number of leaves and maximum leaf area is produced by the same treatment combination. Hence, this treatment combination in the presence of optimum light produced maximum dry matter in the Celosia cristata stem. Kazaz et al., (2011) found variable results in stem dry matter of different cultivars of Carnation. Ali et al., (2006) found significant increase in shoot dry weight and corm dry weight in Gladiolus with nitrogen and $\mathrm{GA}_{3}$ treatment.

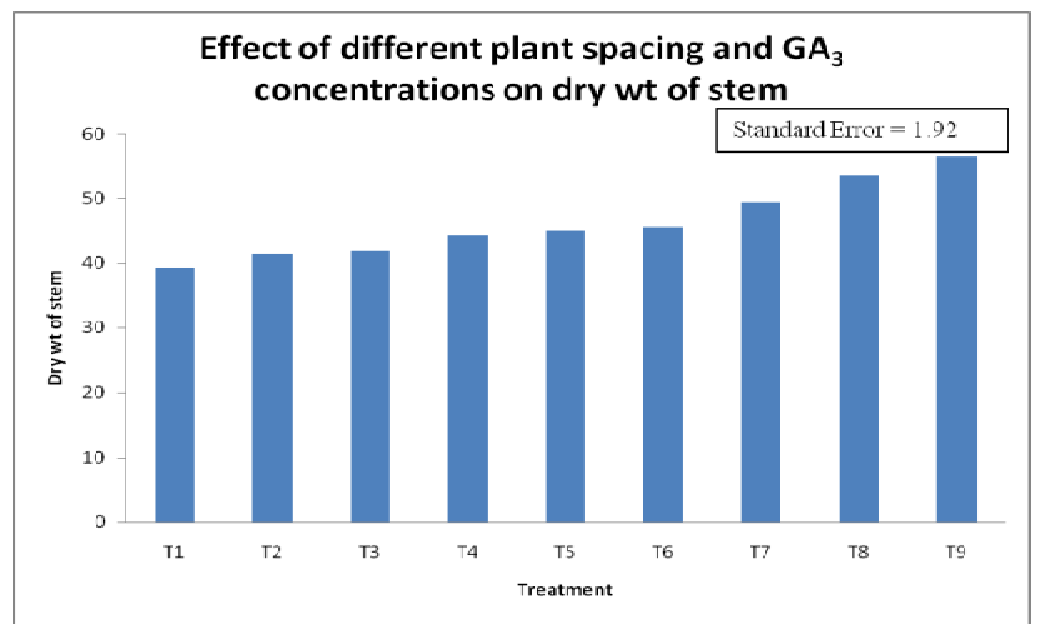

Figure 5 - Effect of different plant spacing and $\mathrm{GA}_{3}$ concentrations on dry weight of stem

Flower size $\left(\mathrm{cm}^{2}\right)$. It is apparent from the data that maximum but statistically insignificant flower sizes of $38.21 \mathrm{~cm}^{2}, 36.20 \mathrm{~cm}^{2}$ and $34.57 \mathrm{~cm}^{2}$ were achieved when plant spacing of $37.5 \mathrm{~cm}, 30 \mathrm{~cm}$, and $22.5 \mathrm{~cm}$ were used respectively and were treated with $50 \mathrm{mg} / \mathrm{L} \mathrm{GA}{ }_{3}\left(\mathrm{~T}_{9}, \mathrm{~T}_{8}\right.$ and $\mathrm{T}_{7}$ respectively). Minimum flower size of $18.36 \mathrm{~cm} 2$ was achieved when plant spacing of $22.5 \mathrm{~cm}$ was used without any $\mathrm{GA}_{3}$ application $\left(\mathrm{T}_{1}\right)$. This result tells that $\mathrm{GA}_{3}$ application plays its role in the production of maximum flower size. Gibberellins are well known for cell enlargement of plants growth and development. It is also reported that stem length and total yield $/ \mathrm{m}^{2}$ increased by increasing plant densities, whereas stem diameter, stem weight and flower diameter per plant decreased in Standard Carnations (Kazaz et al., 2011). The variation in different vegetative and flower parameters may be due to the different growth requirement of Celosia cristata and Carnation for spacing.

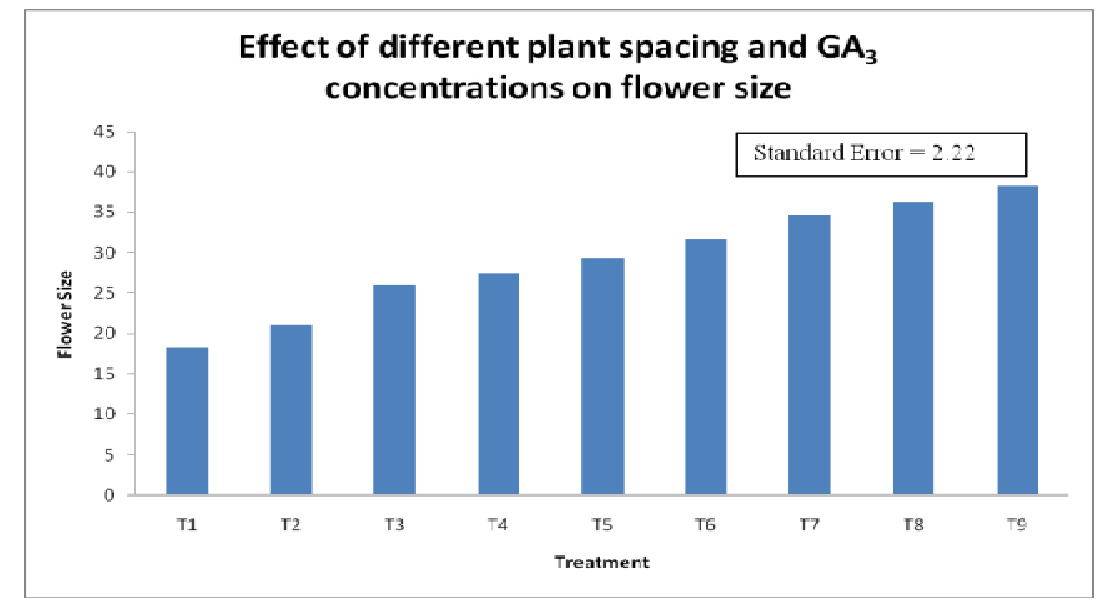

Figure 6 - Effect of different plant spacing and $\mathrm{GA}_{3}$ concentrations on flower size 
Flower Fresh Weight (g). Maximum flower fresh weight of $21.74 \mathrm{~g}$ was achieved when seedling were planted $37.5 \mathrm{~cm}$ apart and $50 \mathrm{mg} / \mathrm{L} \mathrm{GA}_{3}$ was applied $\left(\mathrm{T}_{9}\right)$ against minimum flower fresh weight of $6.08 \mathrm{~g}$ which was achieved when plant spacing of $22.5 \mathrm{~cm}$ was used without $\mathrm{GA}_{3}$ application $\left(\mathrm{T}_{1}\right)$. It seems that plant spacing of $37.5 \mathrm{~cm}$ or $30 \mathrm{~cm}$ in combination with $\mathrm{GA}_{3}$ at the rate of $50 \mathrm{mg} / \mathrm{l}$ may help to develop more number of plant roots and these may be helpful in uptake of more water by the plants. Hence, uptake of more water by the roots may be responsible for better fresh flower weight in Celosia cristata. The results are comparable to the findings of Kishan et al. (2007) who reported maximum fresh weight of single flower in African marigold (Tagetserecta Linn.) cv. PusaNarangiGainda with the application of $\mathrm{GA}_{3}$ at the rate of $300 \mathrm{ppm}$. Increase in fresh weight of flower stalk due to the application of $\mathrm{GA}_{3}$ has already been reported in carnation (Verma et al., 2000) and iris (AlKhassawneh et al., 2006).

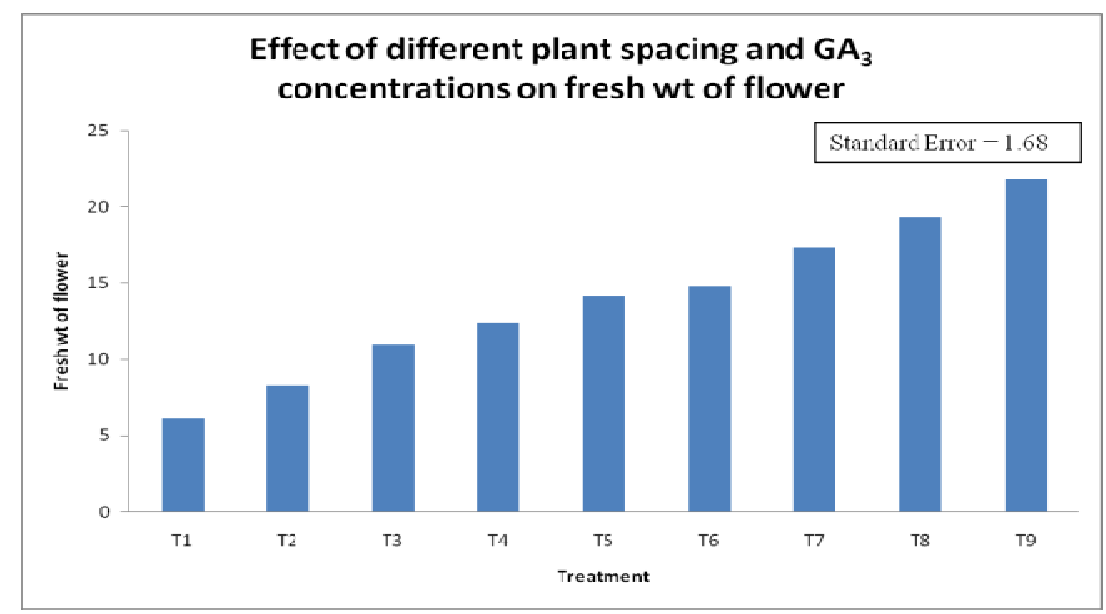

Figure 7 - Effect of different plant spacing and $\mathrm{GA}_{3}$ concentrations on fresh weight of flower

Flower Dry Weight (g). It is evident from results that maximum flower dry weight of $2.92 \mathrm{~g}$ was achieved when plants were spaced at $37.5 \mathrm{~cm}$ apart and were treated with $50 \mathrm{mg} / \mathrm{L} \mathrm{GA} \mathrm{G}_{3}\left(\mathrm{~T}_{9}\right)$ and was statistically highly significant than all other treatments and control. The minimum flower dry weight of $0.69 \mathrm{~g}$ was produced when plant spacing of $22.5 \mathrm{~cm}$ was used with no $\mathrm{GA}_{3}$ application $\left(\mathrm{T}_{1}\right)$. Plant spacing may provide optimum space for better plant growth and plant may have better share of food nutrients as compared to other treatments. On the other hand, $\mathrm{GA}_{3}$ also causes an increase in leaf area and number of leaves in this treatment which ultimately may have influenced in the production of more photosynthates which may have translocated to flower head and accumulated as dry matter.

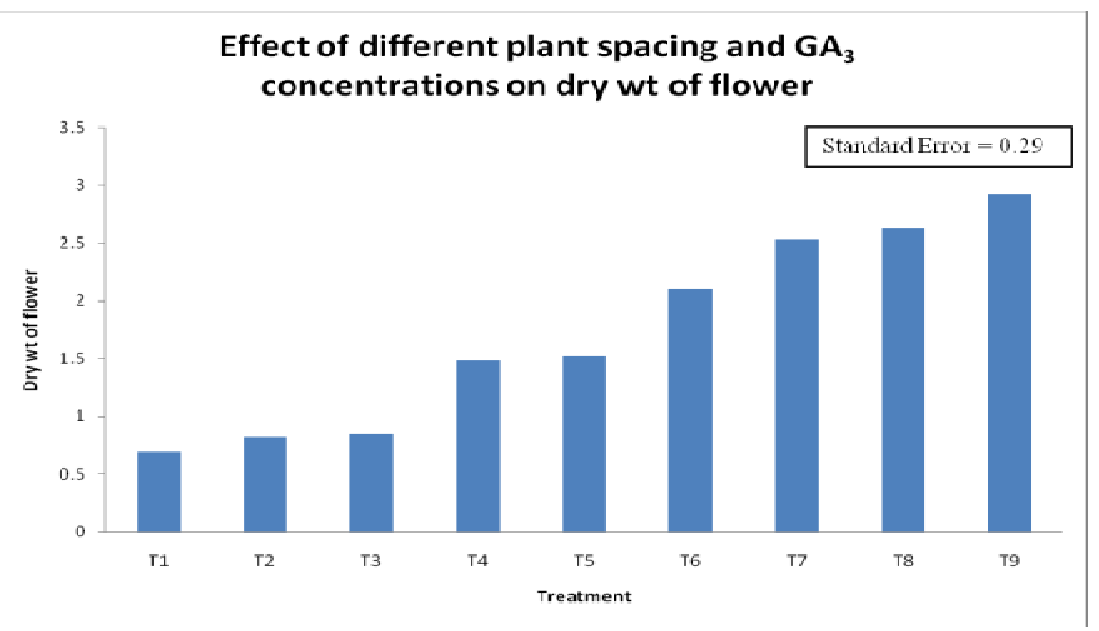

Figure 7 - Effect of different plant spacing and $\mathrm{GA}_{3}$ concentrations on fresh weight of flower 


\section{ACKNOWLEDGEMENTS}

The authors acknowledge the technical assistance and guidance received from Dr. Akbar Anjum and Dr. Shakeel Ahmad, Faculty of Agriculture, Science and Technology, Bahaudin Zakariya University Multan, Pakistan. The staff at the department of horticulture, FAST, Bahauddin Zakariya University Multan is also appreciated for its cooperation during the laboratory analyses.

\section{REFERENCES}

[1] Akinfasoye, J.A., D.J. Ogunniyan, W.B. Akanbi and A.O. Olufolaji, 2008.Effects of organic fertilizer and spacing on growth and yield of Lagos spinach (Celosia Argentea L.). Journal of Agriculture and Social Research (JASR), 8(1): 70-77.

[2] Ali, Y.S.S. and M.S. Al-safar, 2006. Effect of $\mathrm{GA}_{3}$ treatment and nitrogen on growth and development of Gladiolus corms. Pakistan journal of biological sciences 9(13): 25162519.

[3] Al-Khassawneh, N.M., N.S. Karam and R.A.Shibli, 2006.Growth and flowering of black Iris (Iris nigricansDinsm.) following treatment with plant growth regulators.ScientiaHorticulturae, 107: 187-193.

[4] Bhattacharjee, S. K., 1984, Effect of growth regulating chemicals on growth and flowering and tuberous root formation of dahlia variablis. Punjab Horticultural Journal, 24 (1/4): 138-144.

[5] Bhushan, B., S. Mishra and M.A. Hussain, 2006. Effect of planting time and spacing on sprouting and growth attributes in Gladiolus (cv. red beauty) in Bundelkhand region of Uttar Pradesh. Progressive Agriculture, 6(1): 63-65.

[6] Bonarriva, J., 2003. Industry and Trade summary cut flowers, USITC publication, 3580 office of industries, Washington D.C. 20436.

[7] Brian, P. W. Effects of Gibberellins on Plant Growth and Developmentlssue. Biological reviews, 30 (1),37-77.

[8] Bricker, B.1991. MSTATC: A computer program for design management and analysis of agronomic research experiments. Crop and soil science Deptt. MSU East Lancing, MI 48824, USA.

[9] Chandarapa, J. V., N. Gowda, M.C. Gowda and M. Gowda and A. P.M., 2006. Influence of growth regulators and their combination on growth and flower production in Anthurium cv. Royal red. Research on Crops, 7(1): 279-281.

[10] Edwards Thomas I, R. Pearl, and Gould S. A. 1934. The growth and duration of life of celosia cristata seedlings at different temperatures. Journal of General Physiology, 20; 17(6): 763-781.

[11] Emami H., M. saeidnia, J.A. Olfati and M. Hasani, 2011. Study on lily longevity treated with growth regulator $\left(\mathrm{GA}_{3}\right.$ and $\left.\mathrm{BA}\right)$ by path analysis. American-Eurasian J. Agric. and Environ. Sci., 10(5): 814-820.

[12] Emami, H., M. Saeidnia, A. Hatamzadeh, D. Bakhshi, and E. Ghorbani, 2011.The effect of gibberellic acid and benzyladenine in growth and flowering of Lily (Liliumlongiflorum). Advances in Environmental Biology, 5(7): 1606-1611.

[13] Kazaz, S., F.E. Tekintas and M.A. Askin, 2011. Effects of different planting systems and densities on yield and quality in standard Carnations.Cell\& Plant Sciences, 2(1): 19-23.

[14] Khalaj, M.A. and B. Edrisi, 2012.Effect of plant spacing and nitrogen levels on quantity and quality characteristics of Tuberose (polianthestuberosa L.) under field experiment. International Journal of Agriculture Science, 2(3): 244-255.

[15] Khan, F. U. and G. N. Tewari, 2003. Effect of growth regulators on growth and flowering of Dahlia (Dahlia varialibis L.). Indian Journal of Horticulture, 60(2): 192-194.

[16] Kishan, S., K. P. Singh and D. V. S. Raju, 2007. Vegetative growth, flowering and seed characters of african marigold (Tageteserecta Linn.) as influenced by different growth 
substances during mild off seasons. Journal of Ornamental Horticulture, 10(4): 268270.

[17] Mane, P.K., G.J. Bankar and S.S. Makne, 2006.Effect of spacing, bulb size and depth of planting on growth and bulb production of Tuberose (Polianthes tuberose) cv. Single. Indian Journal of Agricultural Research, 40(1): 64-67.

[18] Peanav,R., K. Jitendra, K. Mukesh, 2005. Response of $\mathrm{GA}_{3}$, plant spacing and planting depth on growth, flowering and corm production in Gladiolus. Journal of Ornamental Horticulture, 8(1): 44.

[19] Roychowdhury, N., 1987.Effect of plant spacing and growth regulators on growth and flower yield of gladiolus grown under polythene tunnel. Proceeding of International Symposium on Protected Cultivation of Ornamentals in Mild Winter Climates, ISHS ActaHorticulturae 246.

[20] Steel, R.G. D., J. H. Torrie and D. A. Dickey, 1997. Principles and Procedures of Statistics. A biometrical approach. $3^{\text {rd }}$ Ed., McGraw Hill Book Co., New York, USA.

[21] Verma, V.K., O.P. Sehgal and S.R. Shiman, 2000.Effect of nitrogen and $\mathrm{GA}_{3}$ on Carnation. Journal of Ornamental Horticulture (New series), 3(1): 64.

[22] Wilkinson, C. B., 2006. Year of the Celosia, Chili Pepper.National Garden Bureau

[23] Yarnia, M., M.B.K. Benam, E.F.M. Tabrizi, N. Nobari and V.Ahmadzadeh, 2011.Effect of planting dates and density in drought stress condition on yield and yield components of Amaranth cv. Koniz.Advances in Environmental Biology, 5(6): 1139-1149. 